\title{
Erzurum İli Hınıs İlçesindeki Sığırcılık İşletmelerinin Yapısal Özellikleri: Sağım Yönetimi
}

\author{
Rıdvan KOÇYiĞiTT ${ }^{1}$, Recep AYDIN ${ }^{1}$, Abdülkerim DiLER ${ }^{2}$, Olcay GÜLER ${ }^{3}$, Mete YANAR ${ }^{1 *}$ \\ ${ }^{1}$ Atatürk Üniversitesi Ziraat Fakültesi Zootekni Bölümü Erzurum \\ ${ }^{2}$ Atatürk Üniversitesi Erzurum Meslek Yüksekokulu Bitkisel ve Hayvansal Üretim Bölümü, Erzurum \\ ${ }^{3}$ Atatürk Üniversitesi Hınıs Meslek Yüksekokulu Laborant ve Veteriner Sağlığı Bölümü, Erzurum \\ *Sorumlu yazar:mtyanar@gmail.com
}

\begin{abstract}
Öz
Bu araştırmada, Erzurum ili Hınıs ilçesindeki sığırcılık işletmelerinin sağım yönetimini değerlendirmek amacıyla 378 işletme ile yüz yüze görüşülerek yapılan anketlerden elde edilen veriler kullanılmıştır. işletmelerin \%51.0'inde sağım esnasında ineklere yem verilmediği, \%85.0'inde sağım öncesi meme temizliği yapıldığı ve \%89.2'sinde elle sağım tercih edildiği belirlenmiştir. Sığır yetiştiricilerinin \%73.0'ü sağımdan sonra sütü alüminyum kaplarda bekletmektedirler. Yetiştiricilerin \%68.0'i ineklerinin sonbaharda doğurmasını isterken, \%61.0'i hayvan başına süt veriminin yaz mevsiminde daha çok olduğunu ifade etmektedir. Yetiştiricilerin sadece \%9.0'u devletin vermiş olduğu süt desteklemelerinden faydalanmaktadır. Hınıs ilçesinde sağmal ineklerin yemlenmesi, sağım yönetimi, sütün muhafazası ve devlet teşviklerinden yararlanma konusunda gelişme olmaması önemli sorunlar olarak ortaya çıkmıştır. Bunun nedeni olarak, Hınıs ilçesinde süt sığırcılı̆̆ı ile uğraşan işletmelerin sermaye yetersizliği, bu faaliyeti yapanların bilgi birikimlerinin çok az oluşu yani geleneksel yöntemlerle hayvancılık yapıldığı söylenebilir. Sonuç olarak, bu sorunların çözümü için sığır yetiştiricilerine ilgili konularda eğitim ve danışmanlık desteği verilmesi gerekir.
\end{abstract}

Anahtar Kelimeler: Hınıs ilçesi, Süt sığırcılığı, Meme temizliği, Sağım yönetimi

\section{Structural Characteristics of the Cattle Enterprises in Hinis County of Erzurum Province: Milking Management}

\begin{abstract}
In this study, data obtained from a survey work conducted in 378 enterprises via face-to-face interview method in order to evaluate milking management of the cattle enterprises were used. It was found out that $51.0 \%$ of the enterprises did not offer concentrate to the cows during the milking. While $85.0 \%$ of the enterprises is performing cleaning of the udder, $89.2 \%$ of the enterprises prefers hand milking methods. Seventy-three percent of the cattle ranchers keep the milk in the aluminum containers after the milking. While $68.0 \%$ of the cattle ranchers want their cows to give birth in fall, $61.0 \%$ of them state that milk yield of the individual cow increases in summer. $9.0 \%$ of the cattle breeders utilizes from milk incentives given by the government. Significant problems arisen in Hinis County are feeding of lactating milking cows, milking methods, preservation of the milk and not to be improvement in the utilization from incentives of the government. It could be said that the reasons of these problems are insufficient capital of the enterprises, lack of information about modern livestock production methods in other words they follow traditional methods come from inherited their ancestors. As a conclusion, it was suggested that supports about technical training and consultancy service should be given for solutions of these problems.
\end{abstract}

Key words: Hinis County, Dairy cattle, Udder cleaning, Milking management 


\section{Giriş}

Erzurum, 2015 yılı itibarıyla 779.448 kişilik nüfusa sahiptir. Yüzölçümü $25.066 \mathrm{~km}^{2}$ olup, denizden yüksekliği yaklaşık 1900 m’dir. Temel geçim kaynağı bitkisel ve hayvansal üretime dayalı olup son yıllarda kış turizmi de öne çıkan sektörlerden birisidir. 460 bin hektarlık tarım arazisinin 306 hektarlık bölümü sulanabilir konumda olup, 268 bin hektarlık bölümünde ekim yapılmaktadır. Yüzölçümünün \%15.17'sinde tarım yapılabilir (Anonim, 2015a).

Erzurum ilindeki toplam büyükbaş hayvan sayısı 2015 yılı istatistiklerine göre 641.811 baştır. Erzurum ili Türkiye hayvan varlığının \%4.5'ine sahiptir (TUIK, 2016). Yıllar itibariyle yerli sığır sayısında bir azalma olurken melez ve kültür sığırı yetiştiriciliğinde genel olarak bir artış görülmektedir (Çizelge 1). Toplam büyükbaş hayvan varlığının \%78.0'ini melez sığır, \%13.2'sini kültür ırkı sığır, \%8.4'ünü yerli sığır ve \%0.2'sini ise manda oluşturmaktadır.

Hınıs ilçesi, Erzurum ilinin güneyinde yer almakta olup, il merkezine Erzurum-Muş karayolu üzerinden $150 \mathrm{~km}$, Hınıs-KarayazıErzurum karayolu üzerinden $170 \mathrm{~km}$ uzaklıktadır. İlçenin doğusunda Karaçoban ilçesi, güneyinde Varto ve Bulanık, batısında Varto ve Tekman ilçesi, kuzeyinde Tekman ve Karayazı ilçeleri vardır. İlçenin nüfusu 2014 yılı istatistiklerine göre 28.607 kişi olarak tespit edilmiştir (Anonim, 2015b).

Çizelge 1.Yıllar itibariyle Erzurum ili sığır sayısı (baş) ve genotiplerin payı (\%)

Table 1. Cattle numbers (heads) and proportion of the genotypes (\%) according to years

\begin{tabular}{|c|c|c|c|c|c|c|c|c|c|}
\hline $\begin{array}{c}\text { Yıllar } \\
\text { Years }\end{array}$ & $\begin{array}{c}\text { Yerli } \\
\text { Domestic }\end{array}$ & $\mathbf{\%}$ & $\begin{array}{c}\text { Melez } \\
\text { Crossbred }\end{array}$ & $\%$ & $\begin{array}{c}\text { Kültür } \\
\text { Culture }\end{array}$ & $\%$ & $\begin{array}{c}\text { Manda } \\
\text { Buffaloes }\end{array}$ & $\%$ & $\begin{array}{c}\text { Toplam } \\
\text { Total }\end{array}$ \\
\hline $\mathbf{2 0 1 0}$ & 145.679 & 27.08 & 343.902 & 63.92 & 47.401 & 8.81 & 1.032 & 0.19 & 538.014 \\
\hline $\mathbf{2 0 1 1}$ & 130.584 & 22.21 & 403.980 & 68.70 & 52.327 & 8.90 & 1.116 & 0.19 & 588.007 \\
\hline $\mathbf{2 0 1 2}$ & 107.753 & 17.24 & 447.791 & 71.65 & 68.325 & 10.93 & 1.113 & 0.18 & 624.982 \\
\hline $\mathbf{2 0 1 3}$ & 66.532 & 9.92 & 526.579 & 78.51 & 76.413 & 11.39 & 1.159 & 0.17 & 670.683 \\
\hline $\mathbf{2 0 1 4}$ & 55.818 & 8.51 & 516.589 & 78.76 & 82.161 & 12.52 & 1268 & 0.19 & 655.836 \\
\hline $\mathbf{2 0 1 5}$ & 54.211 & 8.44 & 501.205 & 78.09 & 84.804 & 13.21 & 1591 & 0.24 & 641.811 \\
\hline
\end{tabular}

Hınıs ilçesi Erzurum illinin güneyinde, engebeli, 1720 rakımlı, çevresi dağlarla çevrili bir ova üzerinde kurulmuştur. İçinden kendi adını taşıyan bir çay (dere) geçmektedir. İlçenin yüzölçümü $1199 \mathrm{~km}^{2}$ dir. Tabiat yapısı ve iklim özellikleri bakımından Erzurum'dan az da olsa farklıdır. Erzurum gibi karasal bir iklime sahip olmasına rağmen, kış ayları Erzurum'dan beş ile on derece daha sıcaktır. İlçede halkın ana geçim kaynağı hayvancılıktır (Anonim, 2015c). 2015 yılı itibariyle Hınıs ilçesi büyükbaş hayvan varlığı 38877 baştır. Büyükbaş hayvan varlığının \%7.9'u yerli sığır ırkı, \%11.9'u kültür ırkı sığır, \%79.7'si melez sığır ve \%0.3'ünü ise manda oluşturmaktadır.
Hınıs ilçesindeki sığır varlığı Erzurum toplam sığır varlığının \%6.0'sı kadardır (TUiK, 2016).

Bu çalışmanın amacı Erzurum iline bağı Hınıs ilçesinde bulunan sığırcılık işletmelerindeki sağım yönetimi hakkında mevcut durumu tespit etmek ve elde edilen bilgiler doğrultusunda çözüm önerileri sunmaktır.

\section{Materyal ve Metot}

Araştırmanın materyalini Erzurum ili Hınıs İlçesindeki 5190 süt sığırcılığı işletmesinden 378'ine uygulanan anketler oluşturmuştur. Araştırma anketi 2014 yılında ve işletme sahipleriyle yüz yüze görüşülerek yapılmıştır. 
Anket sayısının belirlemesi ise oransal örnekleme yöntemi ile yapılmıştır. Yöntemde \%95.0 güven aralığı, \%5.0 hata payı ile aşağıdaki formül kullanılmıştır (Newbold, 1995).

$$
\mathrm{n}=\frac{\mathrm{N}^{*} \mathrm{p}^{*}(1-\mathrm{p})}{(\mathrm{N}-1)^{*} \sigma_{\mathrm{p}}^{2}+\mathrm{p}^{*}(1-\mathrm{p})}
$$

Formülde;

n : Örnek büyüklüğü,

$\mathrm{N}$ : Üretici sayısı,

$\sigma_{\mathrm{p}}^{2}$ : Oranın varyansı,

$Z_{\alpha / 2}: Z$ cetvel değeri

p : İşletme sayısının popülasyondaki oranını göstermektedir.

$$
\begin{aligned}
& {\sigma_{p}}^{2}=\frac{0.05}{1.96}=0.0255 \\
& n=\frac{5190 * 0.5 * 0.5}{\left(5189 * 0.0255^{2}\right)+(0.5 * 0.5)}=357.95
\end{aligned}
$$

Araştırmada anket sayısı \%5 (20 adet) artırılarak Hınıs İlçesi'nde toplam 378 yetiştirici ile anket yapılmıştır. Elde edilen veriler Excel 2010 Programına aktarılarak elde edilen faktörlere uygun grafikler oluşturularak yorumlanmıştır.

\section{Araştırma Bulguları ve Tartışma}

İşletmecilerin \%51.0'inde süt sığırlarına sağım esnasında yem verilmediği, \%28.0'i sağımdan önce, \%13.0'ü sağımdan sonra ve \%8.0' $i$ ise sağım esnasında yem verildiği belirlenmiştir (Şekil 1). Sağım esnasında yem verme oranı Kahramanmaraş'ta \%58.0, (Kaygısız ve ark., 2008), Tekirdağ yöresinde \%69.0 (Soyak, 2006), Tokat yöresinde \%44.4 (Ildız, 1999) olarak belirlenmiştir. Sağmal ineklerin verim payı genellikle kesif yemlerle karşılandığından ineklere kesif yem verilmemesi süt veriminin azalmasına, vücut dokularının harcanmasına, dolayısı ile hem hayvanların vücut kondisyonunun düşmesine hem de bağışıklık sisteminin zayıflamasına neden olabilmektedir. Tüm bunlar da işletmelerin ekonomik değer kaybına neden olmaktadır.

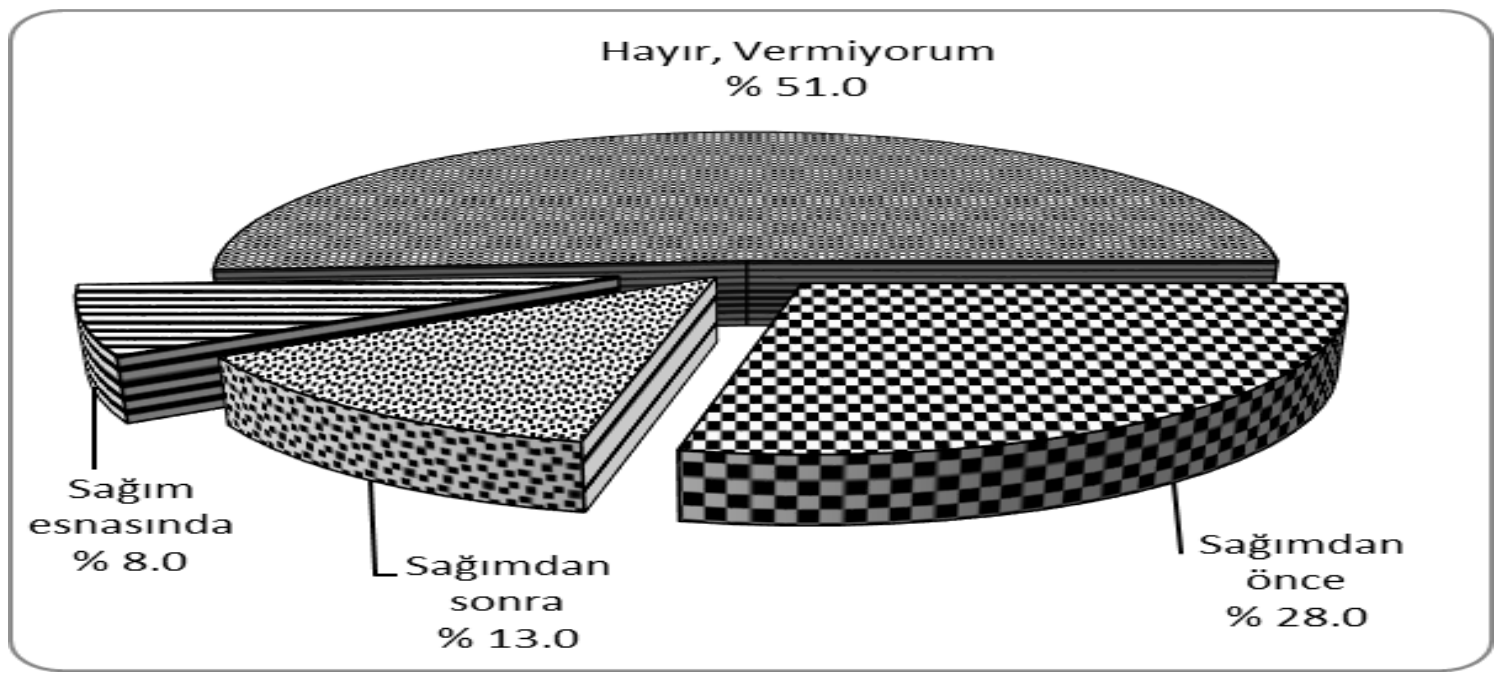

Şekil 1.Sağım esnasında kesif yem verme

Figure 1.Giving concentrate feed during milking 
Ankete katılan işletmelerin \%89.0'ında elle sağımın yapıldığı, seyyar makine ile sağımın \%10.0 oranında, sağım ünitesinde sağım yapan işletmelerin oranının ise \%1.0 gibi çok düşük oranlarda yapıldığı tespit edilmiştir (Şekil 2). Elle sağım yapan işletme oranı Doğu Anadolu'da daha yaygın olduğu belirlenmiştir. Nitekim elle sağım yöntemi Van'da \%96.5 (Bakır, 2001), Erzincan ili çayırlı ilçesinde \%81.0 (Özyürek ve ark., 2014) ve Kars ilinde \%78.4 (Demir ve ark., 2014) olarak benzer sonuçlar bildirilmiştir. Marmara ve İç Anadolu Bölgesinde ise makine ile sağımın daha yaygın olduğu belirlenmiştir. Örneğin Tekirdağ ilinde makine ile sağım oranını Akman ve Özder, (1992) \%76.0, Soyak ve ark., (2007) \%93.0 olarak, Tatar (2007) Ankara'da \%95.2, Aksaray'da ise \%94.4 olarak ve Önal ve Özder (2008) ise Edirne ilinde tüm işletmelerin sağımı makine ile yaptıklarını rapor etmişlerdir.

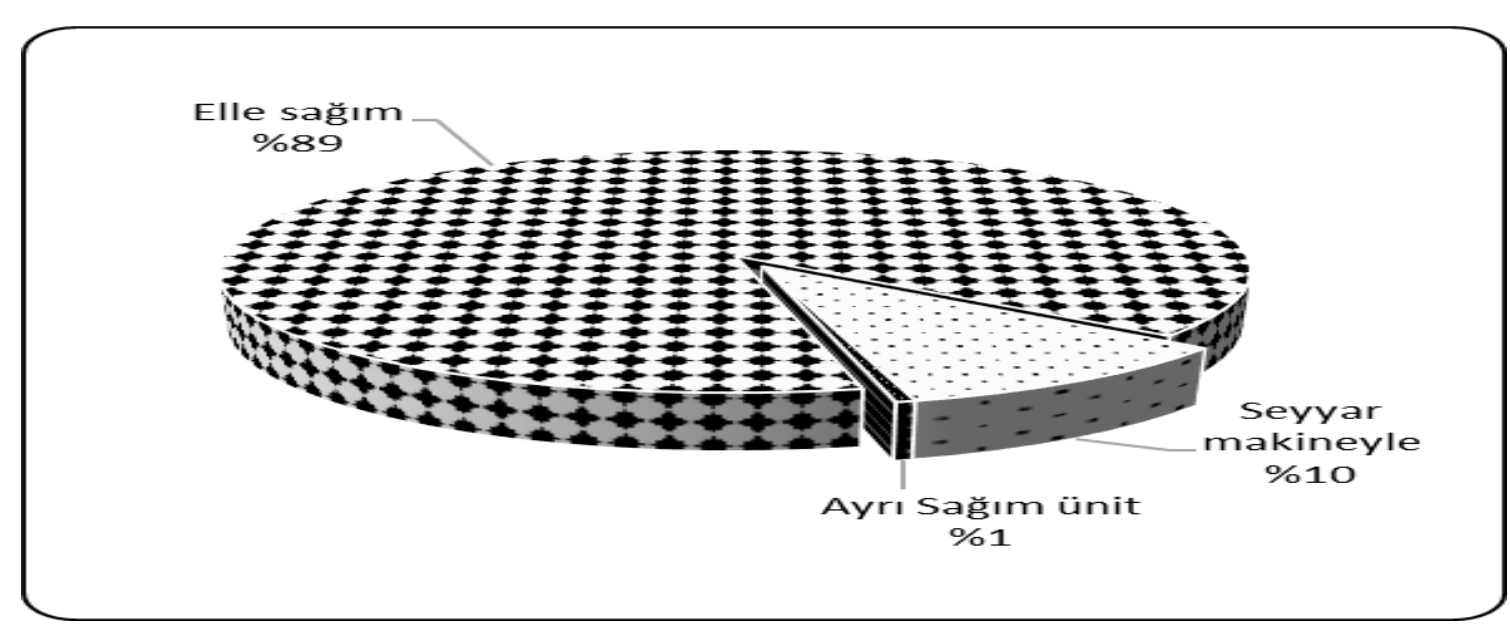

Şekil 2. Sağım şekli

Figure 2. Type of milking

Bogdanovic ve ark., (2012) Sırbistan'da süt sığırcılı̆̆ı yapan işletmelerin yaygın olarak kullandıkları 3 farklı sağım sistemi mevcut olduğunu (balık kılçığı sağım sistemi, özel süt toplama makinaları ile sağım ve vakumlu boru hattı) ve özellikle büyük işletmelerde balık kılçığı şeklinde otomatik sağım sistemi, küçük işletmelerde ise özel süt toplama makinaları ile sağım ve vakumlu boru hattı sağım sistemiyle sağım yapıldığını ifade etmişlerdir.

İşletmelerin \%85.0'inde sağım öncesi meme temizliği yapıldığı, \%15.0'inde meme temizliği yapılmadığı tespit edilmiştir (Şekil 3). Türkiye'de sağım öncesi meme temizliğine büyük ölçüde özen gösterildiğini gösteren çalışmalar bulunmaktadır. Nitekim sağım öncesi meme temizliği oranı, Ildız (1999)'ın
Tokat yöresi için \%66.6, Soyak (2006) Tekirdağ ilinde \%96.0, Tatar (2007) Ankara ve Aksaray'da sırasıyla \%98.4 ve \%96.5, Kaygısız ve ark., (2008) Kahramanmaraş'ta \%78.0, Özyürek ve ark., (2014) Erzincan ili Çayırlı ilçesinde \%93.3 ve Demir ve ark., (2014) Kars ilinde \%52.5 olarak bildirmişlerdir. Bulduğumuz sonuçlar Ildız (1999) ile Demir ve ark., (2014)'nın bildirişlerinden yüksektir. Ankete katılan işletmelerde sağım öncesi meme temizliğine önem verildiği söylenebilir. Ancak sağım öncesi meme temizliği yapmayan işletmelerin oranının $\% 15.0$ olduğu tespit edilmiştir. Bunun için bu işletmelerin sağım ve hijyen konularında bilgilendirilmesi yararlı olacaktır. 


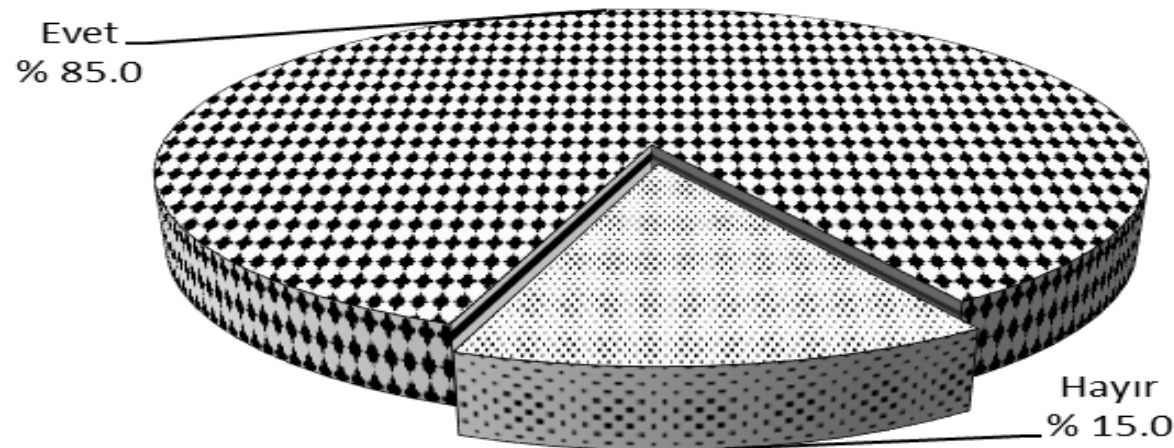

Şekil 3. Sağım öncesi meme temizliği

Figure 3. Udder cleaning prior to milking

Sırbistan'da yapılmış olan bir çalışmada Bogdanovic ve ark., (2012) sağım öncesi meme temizliğine yetiştiricilerin oldukça önem verdiklerini bildirmişlerdir.

Buzağıların mera dönemine kadar büyümesi ve meraya çıkabilecek kondüsyona ulaşabilmeleri için ankete katılan işletmelerin \%68.0'i doğumların sonbaharda olmasını isterken \%6.0'sı doğumların kış mevsiminde olmasını arzu etmektedirler (Şekil 4). Benzer şekilde Çoban ve ark., (2013) tarafından yapılan bir çalışmada da yetiştiricilerin \%83.9'unun buzağılama mevsiminin kış ve ilkbahar aylarında olmasını istediklerini rapor etmişlerdir. Bunun nedeni buzağıların mera dönemine kadar büyümesi ve meraya gidebilecek kadar gelişmiş olması istenmiş olabilir.

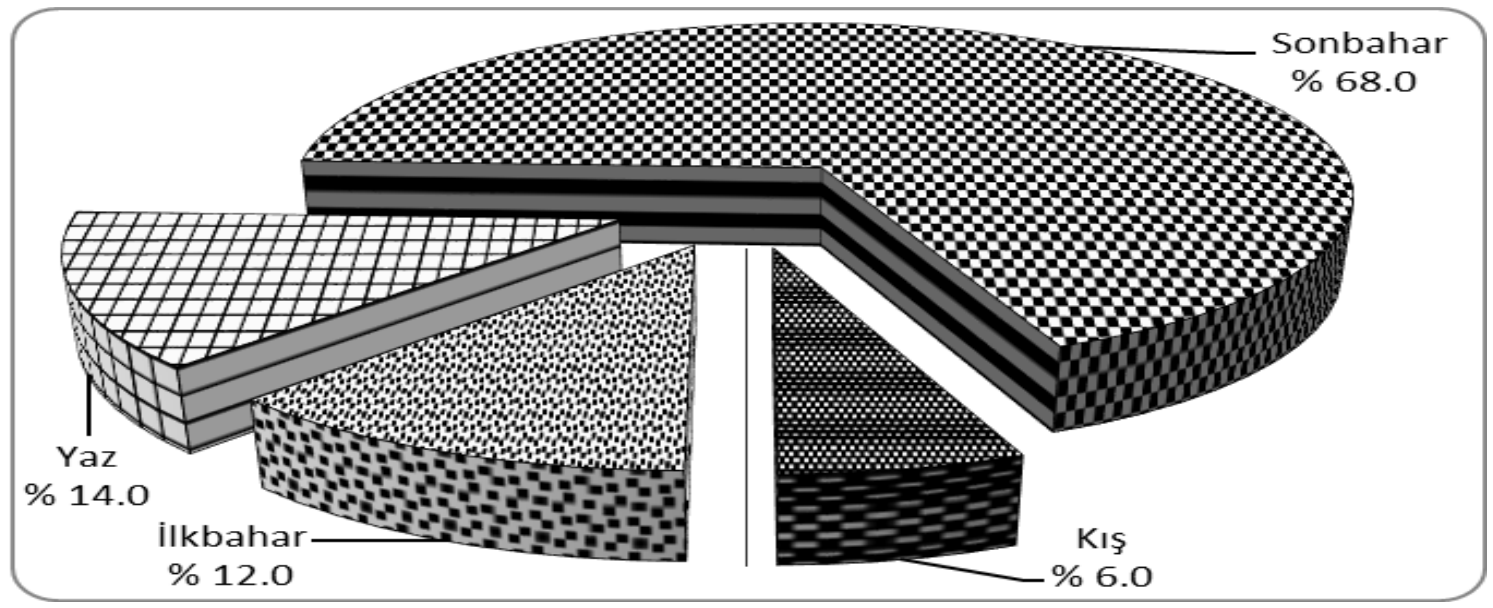

Şekil 4. İneklerin doğurması istenen mevsim

Figure 4. Calving season desired

İşletmecilerin \%61.0'inde hayvan başına süt veriminin en çok yaz aylarında arttığı tespit edilmiştir (Şekil 5). Bu durum ilkbahar sonuna doğru merada sulu yeşil yem tüketiminin artması sonucu süt veriminde de artış sağlanmasından kaynaklanmış olabilir.
İşletmelerin \%73.0'ü sütü alüminyum kovalarda bekletirken \%11.0'i soğutma tankında, \%5.0'i ortak kullanımlı soğutma tankında ve \%11.0'i ise diğer şekilde sütü sağım sonrasında beklettikleri belirlenmiştir (Şekil 6). 


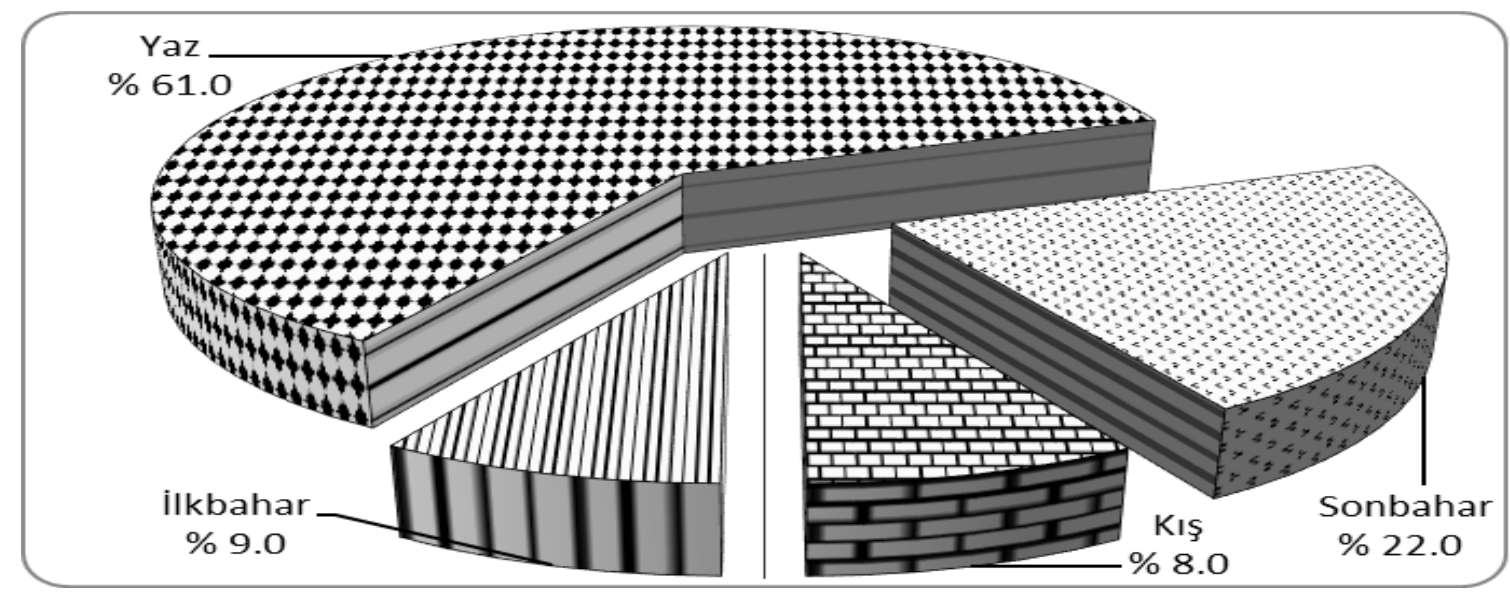

Şekil 5. Hayvan başına süt veriminin daha fazla olduğu mevsim

Figure 5. The highest milk yield season obtained from per animal

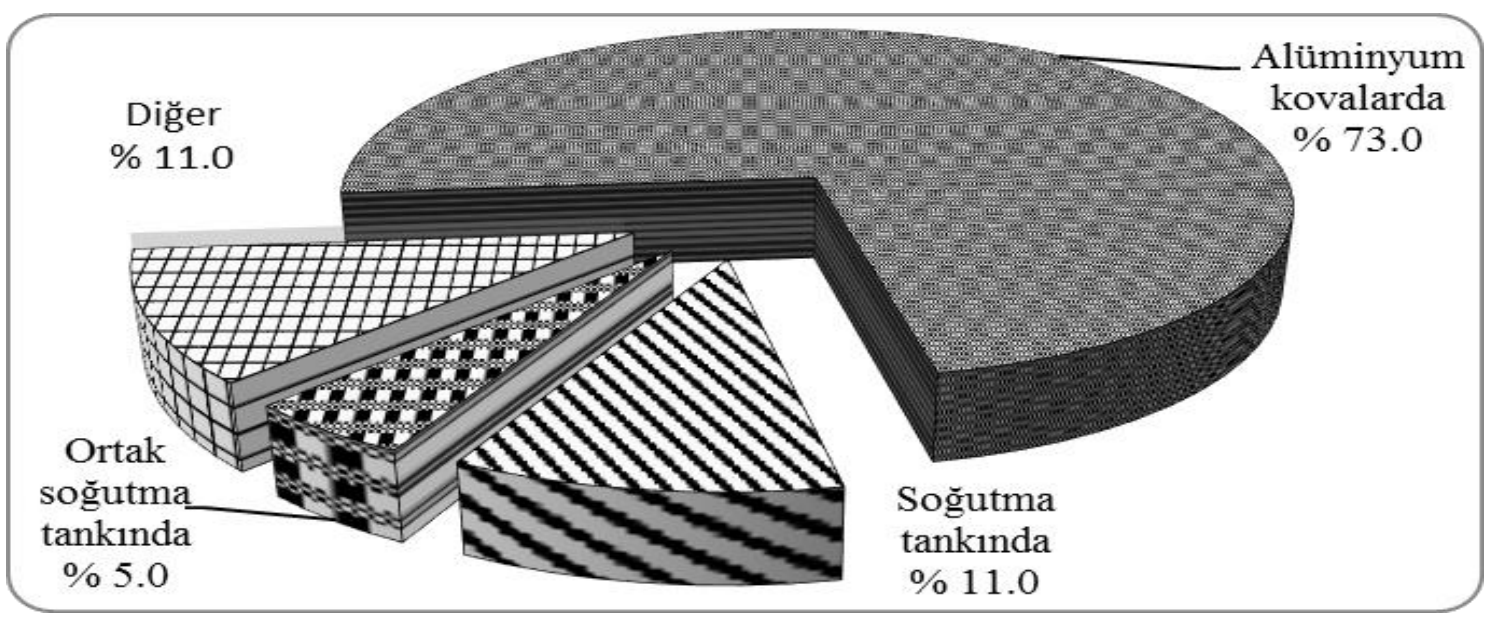

Şekil 6. Sağım sonrası sütün bekletildiği yer

Figure 6. Milk storage places after milking.

İşletmelerin bulunduğu yerlerde soğutma tankı bulunma durumu, süt toplama merkezinin ya da süt taşıyıcıların bulunma durumu sütün saklanmasını etkilemektedir. Sütün sağııkı ve hijyenik olarak saklanması için istenilen soğutma tankında bekletilmesidir. Sağım sonrasında sütü soğuk zincir bozulmadan sağlıklı olarak tüketileceği yere ulaştırıması gerekir. Çalışmada sütü soğutma tankı ve ortak soğutma tankında depolayan işletmelerin oranı \%16.0 kadardır. Ekonomik değer taşıyan sütlerin soğuk zincir kurularak sağlıklı ve hijyenik olarak mandıra ya da süt fabrikasına ulaştırılması için tedbirler alınmalıdır. Bu konuda işletmecilerin bilinçlendirilmesi, soğuk zincir akışının sağlanması, temiz ve kaliteli süt elde etme konusunda bilgilendirilme yapılması gerekmektedir. 


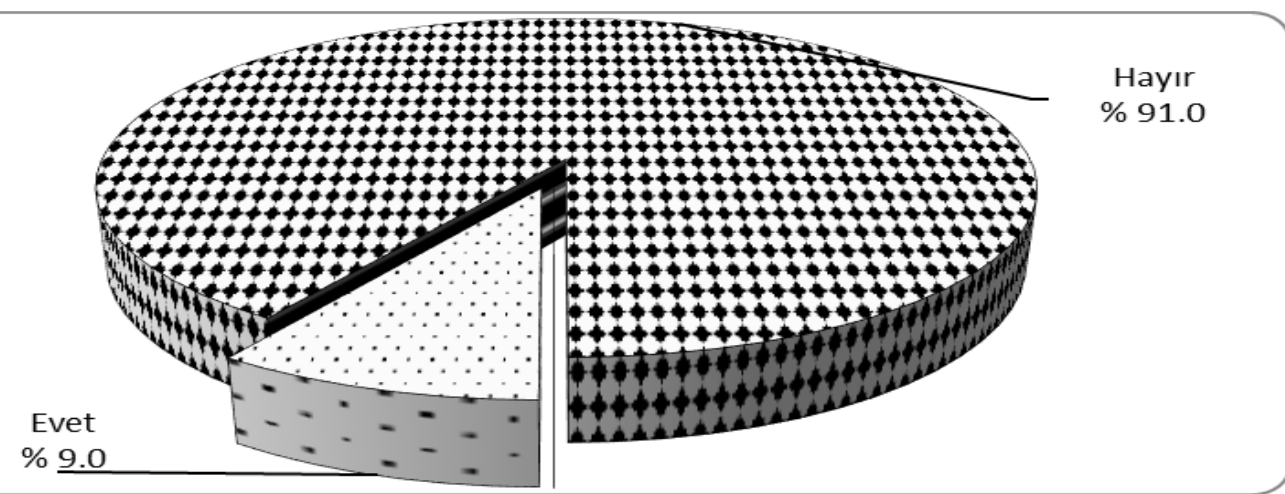

Şekil 7. Süt desteklemesinden faydalanma

Figure 7. Utilizing from milk incentives

Hınıs ilçesinde işletmecilerin sadece \%9.0'unun devletin süt destekleme programlarından yararlandığı tespit edilmiştir (Şekil 7). Bu işletmelerin teşvik için istenen koşulları sağlayamaması, bir kooperatif veya birliğe üye olmaması gibi nedenler süt destekleme oranının az olmasına sebep olmuş olabilir.

\section{Sonuçlar}

Sonuç olarak, Hınıs ilçesinde sağmal ineklerin yemlenmesi, sağım yöntemi, sütün muhafazası ve devlet teşviklerinden yararlanma konusunda gelişme olmaması önemli sorunlar olarak ortaya çıkmıştır. Hınıs ilçesinde süt sığırcılığı ile uğraşan işletmelerin sermaye yetersizliği, yeniliklerden uzak kalması, bu faaliyeti yapanların bilgi birikimlerinin çok az oluşu yani daha çok geleneksel yöntemlerle hayvancılık yapmaları problemin ana nedenleri arasında sayılabilir. Bu sorunların çözümü için, yetiştiricilerin ilgili konular hakkında bilgilendirilmesi gereklidir. Tarım İl ve İlçe Müdürlüklerinin yetiştiricileri her türlü desteklemeler hakkında zamanında bilgilendirmesi, İşletmelerini modernize etmek ve büyütmek isteyenler için çeşitli destek ve kredi imkanları sunulması ve üreticilerin bunlardan faydalanmalarının sağlanması, koşulların nasıl sağlanacağı, bunun sağlanması durumunda kazançlarının ne olacağı hususunda üreticiyi bilinçlendirme çalışmalarını daha etkin bir şekilde gerçekleştirmesi önerilebilir. Ayrıca çiftçi eğitimi ve danışmanlık konusunda yükseköğretim kurumlarından da yararlanılabilir.

\section{Kaynaklar}

Akman, N., Özder, M. 1992. Tekirdağ ilinde ithal ineklerle çalışan işletmelerin durumu ve sorunları. Trakya Bölgesi 1. Hayvancılık Sempozyumu. Tekirdağ, 1992.

Anonim, 2015a. http://tr.wikipedia.org/wiki/ Erzurum. Erişim tarihi: 26.03.2016.

Anonim, 2015b. https://tr.wikipedia.org/wiki/ H\%C4\%B1n\%C4\%B1s\#N.C3.BCfus_ve_sosy al_yap.C4.B1 Erişim tarihi: 26.03.2016.

Anonim, 2015c. http://www.mekan360.com/ 360fx_erzurumhinisilcesi-erzurum hinis.html. Erişim tarihi: 26.02.2015.

Bogdanovic, V., Dedovic, R., Perisic, P., Stanojevic, D., Petrovic, M.D., Trivunovic, S., Kucevic, D., Petrovic, M.M. 2012. An assesment of dairy farm structure and characteristics of dairy production sytems in Serbia. Biotechnology in Animal Husbandry, 28 (4): 689-696.

Çoban, O., Lacın, E., Sabuncuoglu, N., Genc, M. 2013. Production and health parameters in cattle herds: A survey from Eastern Turkey. The Journal of Animal and Plant Sciences, 23(6):1572-1577.

Demir, P., Adıgüzel , S.I., Sarı, M., Ayvazoğlu, C. 2014. Kars merkez ilçedeki süt sığırcılık işletmelerinin genel yapısı ve ekonomik 
boyutu. Fırat Üniversitesi Sağlık Bilimleri

Veteriner Dergisi, 28(1): 9-13.

Ildız, F. 1999. Tokat ili merkez ilçesinde ithal sığır yetiştiren tarım işletmelerinin yapısı. Ankara Üniversitesi Fen Bilimleri Enstitüsü, Zootekni Anabilim Dalı. (Yüksek Lisans Tezi, Basılmamış). Ankara.

Kaygısız, A., Tümer, R., Orhan, H., Vanlı, Y. 2008. Kahramanmaraş bölgesi süt sığırı işletmelerinin yapısal özellikleri: I. Yetiştirme uygulamaları. Süleyman Demirel Üniversitesi Ziraat Fakültesi Dergisi, 3(2): 23-31.

Newbold, P. 1995. Statistics for Business and Economics. Prentice-Hall International, New Jersey.

Önal, A.R., Özder, M. 2008. Edirne ili damızlık sığır yetiştiricileri birliğine üye işletmelerin yapısal özellikleri. Tekirdağ Ziraat Fakültesi Dergisi. 5 (2):197-203.

Özyürek, S., Kocyigit, R., Tüzemen, N. 2014. Erzincan illinde süt sığırcılığı yapan işletmelerin yapısal özellikleri: Çayırılı İlçesi örneği. Tekirdağ Ziraat Fakültesi Dergisi, 11(2):19-26.

Soyak, A. 2006. Tekirdağ ili süt sığırcılığı işletmelerinin yapısal özellikleri ve bu işletmelerin Siyah Alaca süt sığırı populasyonunun çeşitli morfolojik özellikleri üzerine bir araştırma. Yüksek Lisans Tezi, Trakya Üniversitesi, Fen Bilimleri Enstitüsü, Tekirdağ.

Soyak, A., Soysal, M.İ., Gürcan, E.K. 2007. Tekirdağ ìli süt sığırcılığı işletmelerinin yapısal özellikleri ve bu işletmelerdeki Siyah Alaca süt sığırlarının çeşitli morfolojik özellikleri üzerine bir araştırma. Tekirdağ Ziraat Fakültesi Dergisi, 4 (3):297-305.

Tatar, A. M. 2007 Ankara ve Aksaray damızlık sığır yetiştiricileri il birliklerine üye süt sığırı işletmelerinin yapısı ve sorunları. Doktora Tezi, Ankara Üniversitesi, Fen Bilimleri Enstitüsü, Ankara.

TUiK. 2016. TUiK Türkiye istatistik kurumu web sayfası.http://tuikapp.tuik.gov.tr/hayvancı lıkapp/hayvancilik.zul. Erişim tarihi: 26.03.2016. 